\title{
Performance of cobalt oxide/carbon cloth composite electrode in energy generation from dairy wastewater using microbial fuel cells
}

\author{
Vinothkumar Veeramani ${ }^{1}$, Kanimozhi Rajangam ${ }^{1 *}$ and Jaya Nagendran ${ }^{2}$
}

\begin{abstract}
The use of non-noble metal catalyst as electrode for energy harvesting device have drawn great deal of attention owing to its distinct features. In this work, cobalt oxide has been directly fabricated on carbon cloth substrates using simple cost effective Successive Ionic Layer Adsorption and Reaction. Cobalt oxide synthesized from Co (II) nitrate and $\mathrm{NaOH}$ was used as the electrode for generation of electricity from dairy wastes using Microbial Fuel Cells (MFC). Electrochemical characteristics such as cyclic voltammetry have been carried out for the cobalt oxide/ carbon cloth and the obtained results are found to be a good alternative for platinum catalyst. A current of $0.15 \mathrm{~mA}$ was obtained at an external resistance of $2 \mathrm{k} \Omega$. A single cell prototype of double chamber MFC is designed and the performance analysis is carried out in this work.
\end{abstract}

Keywords: Cobalt oxide, Successive ionic layer adsorption and reaction, Microbial fuel cells, Bioelectric generation

\section{Introduction}

Microbial Fuel Cells (MFC) is an alternative energy source that produces electricity in a bioelectrochemical way [1-6]. Because of this, the MFC finds applications in various fields like powering a low power sensor and wastewater treatment of industrial effluents, among others. The catalyst plays a vital role in the MFCs for improving their power density and current density [7-10]. Materials, like metal oxides and activated carbon, are all used as the coating materials for electrodes to improve the performance of MFCs [11]. Many modified stainless steel anode materials have been reported, e.g., zinc-cobalt coated in mild steel $[12,13]$, graphene oxide modified anode [14], polyaniline modified stainless steel anode [15], and polypyrrole coated anode for corrosion resistance [16] which

\footnotetext{
* Correspondence: kanipandian17@gmail.com

${ }^{1}$ Department of Electrical and Electronics Engineering, Anna University - BIT Campus, Tiruchirappalli 620 024, India

Full list of author information is available at the end of the article
}

give some limited performance than the carbon electrode materials. Stainless steel electrodes have the drawback of high internal resistance and corrosion effect. On the other hand, activated carbon materials have also been used for the anode and cathode electrode from various forms of the waste materials like the rubber tires [17], sewage sludge [18], etc. Modified carbon materials show good result than the bare carbon electrodes [19, 20]. Metal oxide coated with carbon material provides improvement in the performance of the MFCs. Platinum coated with carbon is one of the most successful combinations of the metal oxides with good electrochemical behavior. Platinum utilized as catalyst in the MFC can be supplanted by non-noble metals such as metal oxides $[21,22]$ which are inexpensive substitutes to platinum. However, the use of platinum in electrode material is costly than other metal oxides. Many metals such as nickel, graphene, Fe, $\mathrm{Zn}$ and Co are coated in the carbon electrode of the MFC. Cobalt oxide is one

(c) The Author(s). 2020 Open Access This article is licensed under a Creative Commons Attribution 4.0 International License, which permits use, sharing, adaptation, distribution and reproduction in any medium or format, as long as you give

appropriate credit to the original author(s) and the source, provide a link to the Creative Commons licence, and indicate if changes were made. The images or other third party material in this article are included in the article's Creative Commons licence, unless indicated otherwise in a credit line to the material. If material is not included in the article's Creative Commons licence and your intended use is not permitted by statutory regulation or exceeds the permitted use, you will need to obtain permission directly from the copyright holder. To view a copy of this licence, visit http://creativecommons.org/licenses/by/4.0/ 
of the low cost metal oxides and has the ability to increase its surface area when coated on the electrode. This electrode is employed for the treatment of dairy waste and also improves the power density and current density of MFC. Synthesis of cobalt oxide for the oxygen reduction reaction in the cathode was depicted by Xia e al [23]. for a single chamber MFC and only used in the cathode side. In this work, cobalt oxide is coated on carbon cloth for both anode and cathode electrodes in double chamber MFC.

Industrial effluent like dairy waste water is treated in MFC to produce the electricity. Dairy waste water is rich in organic substrate which is a much suitable wastewater for the production of electricity. In addition, potassium ferricyanide is added in the cathode side of the MFC as an electron acceptor for improving the voltage output as investigated by others [24]. The concentration of the potassium ferricyanide is varied to investigate the output performance of the dairy based - Double Chamber MFC (DB-DCMFC) [7].

\section{Materials and methods MFC construction}

The DB-DCMFC is constructed with plexiglass with a dimension of $6 \times 12 \times 8 \mathrm{~cm}$ with a total volume of 500 $\mathrm{mL}$. The schematic of the DB-DCMFC is shown in Fig. S1 in Supplemental Information. Both the electrodes for the anode and cathode are made up of carbon cloth and copper wire is attached to the cloth. Cobalt oxide is coated with the carbon cloth and utilized in both anode and cathode side of the MFC. The two chambers are provided with inlet and outlet paths for refilling and releasing the wastewater after use. Nitrogen gas is purged into the anodic chamber to ensure anaerobic environment and it is airtight to make sure that air will not oxidize the electrons on the anode side.

The two chambers of the MFC are separated by Nafion membrane which is also called Proton Exchange Membrane and is used to allow only the hydrogen ions into the cathode chamber. Here the carbon cloth coated with cobalt oxide is directly utilized in the inoculum from the dairy wastewater for acquiring the electrons. The block diagram of the MFC process is shown in Fig. S2.

\section{Electrode preparation}

A variety of materials is used as the electrodes in MFCs. In this present study carbon cloth electrode is used with the double chamber MFC using dairy wastewater as the influent. Cobalt oxide is coated on carbon cloth using Successive Ionic Layer Adsorption and Reaction (SILAR) technique and it is used as electrode in the DB-DCMFC. Initially $0.05 \mathrm{M}$ of Co (II) nitrate was dissolved in 100 $\mathrm{mL}$ of double distilled water and stirred in magnetic stirrer until cobalt completely dissolves in water. Similarly, $0.05 \mathrm{M}$ of $\mathrm{NaOH}$ is dissolved in $100 \mathrm{~mL}$ of double distilled water and stirred well using magnetic stirrer. Anionic solution (1 M) of Co (II) nitrate hexahydrate and cationic solution $(1 \mathrm{M})$ of $\mathrm{NaOH}$ were coated in the carbon cloth material with the help of SILAR coating system for 25 cycles at a dip time interval of $40 \mathrm{~s}$ each in the $\mathrm{Co}$ (II) nitrate and $\mathrm{NaOH}$. After 25 cycles of coating the carbon cloth, it turned into light brown color due to the cobalt coating on the carbon cloth. The loading of cobalt oxide after coating is $156 \mathrm{mg} \mathrm{cm}^{-2}$ by using weight gain method. The electrode preparation part is depicted in the block diagram as shown in Fig. S2.

\section{Microorganisms and medium}

Bacteria in the dairy wastewater are utilized as the biocatalysts for the generation of electricity. Dairy wastewater from the local dairy industry in Tiruchirappalli, Tamil Nadu, India is taken and analyzed for $\mathrm{pH}$, Biological Oxygen Demand (BOD) and Chemical Oxygen Demand (COD). The $\mathrm{pH}$ range for this dairy waste water is from 7.0 to 8.5 , COD ranges from 1200 to $1589 \mathrm{mg} \mathrm{L}^{-1}$, BOD ranges from 850 to $983 \mathrm{mg} \mathrm{L}^{-1}$ and total dissolved solids ranges from 1000 to $1200 \mathrm{mg} \mathrm{L}^{-1}$ at the room temperature.

\section{Experimental conditions}

In the two chamber of the DB-DCMFC, one chamber on the left hand side is chosen as the anode chamber, 270 $\mathrm{mL}$ dairy wastewater inoculum is filled with carbon cloth as the anode and the cathode chamber on the right hand side of the MFC is supplied with open air and potassium ferricyanide initially of $0.05 \mathrm{M}$ added. After this operation, the catholyte concentration is varied and the output is recorded till the voltage is exhausted. Another setup of the same parameters for dairy wastewater with cobalt oxide coated carbon cloth is taken. The same procedures are repeated for this setup also. The hydrogen ions from the anode side will penetrate through the membrane and combine with the oxygen to produce water molecules. When the voltage level reduces, the chamber is refilled with the wastewater. The hardware setup of the DB-DCMFC is shown in Fig. S3.

\section{Electrical measurements}

The output voltage $(\mathrm{V})$ of the MFC is measured using the precision multimeter and is noted for every $30 \mathrm{~min}$. Both the open circuit voltage and closed circuit voltage with three different resistances values are measured respectively.

The power (P) and current (I) are calculated using Ohm's law Eqs. (1) and (2). 


$$
\begin{aligned}
& I=\frac{V}{R_{\text {ext }}} \\
& P=\frac{V^{2}}{R_{\text {ext }}}
\end{aligned}
$$

Where $R_{\text {ext }}$ is the external resistance connected to the circuit. The external resistances values are varied from $50 \Omega$ to $2 \mathrm{k} \Omega$ and the output voltage values are recorded and utilized to draw the polarization curve. The power density and current density are calculated with the surface area of the electrode. The $\mathrm{pH}$ of the substrate is monitored time to time with the help of the $\mathrm{pH}$ meter to ensure the appropriate value of $\mathrm{pH}$. The internal resistances are measured by the polarization slope method. The MFC will discharge the electrons until the organisms are present in the inoculum after which it is changed with fresh wastewater and the MFC takes an hour to attain the steady state.

\section{Results and discussion}

The dairy wastewater is loaded in the anode side of the double chamber MFC and potassium ferricyanide solution of $0.05 \mathrm{M}$ intial concentration on the cathode side of the MFC. Both the electrodes are at equal distance from the membrane inside the chamber since the distance plays a significant factor for the change in power density [22]. The distance should be as much as low as possible to attain a higher power density. The maximum open circuit voltage obtained is $370 \mathrm{mV}$ in the DBDCMFC with plain carbon cloth as the anode on the second day of the operation. Fresh wastewater is replaced after it comes to the lowest point of voltage drop value of $60 \mathrm{mV}$. The open circuit potential of the modified carbon cloth electrode is $750 \mathrm{mV}$ which is twice as much as the plain carbon cloth electrode. The open circuit characteristic of MFC is shown in the Fig. 1. After every $20 \mathrm{~h}$ of operation the voltage of the MFC is dropped. The wastewater is refilled with new inoculum in which the MFC reactor will take some time to regain to its higher point of voltage. The open circuit voltage is the total potential that the MFC can produce without any resistive load connected across the anode and cathode.

\section{Characteristics at different loading rates}

A curve based on changing the values of the external resistance is plotted with the function of voltage and current. The resitance value is varied from $50 \Omega$ to $2 \mathrm{k} \Omega$ as shown in the Fig. 2 for both coated and non-coated carbon electrode. The value of resistance is changed in descending order because of the solidity of the voltage in the DB-DCMFC. The maximum current generation can be observed at the lower value of the resistance because of release of more electrons. The current and voltage curves against the resistance look inversely proportional to each other. The voltage starts increasing as the resistance increases and attains a value of $560 \mathrm{mV}$ as shown in the Fig. 2 for the coated carbon cloth with a corresponding current value of $0.15 \mathrm{~mA}$ at closed circuit condition.

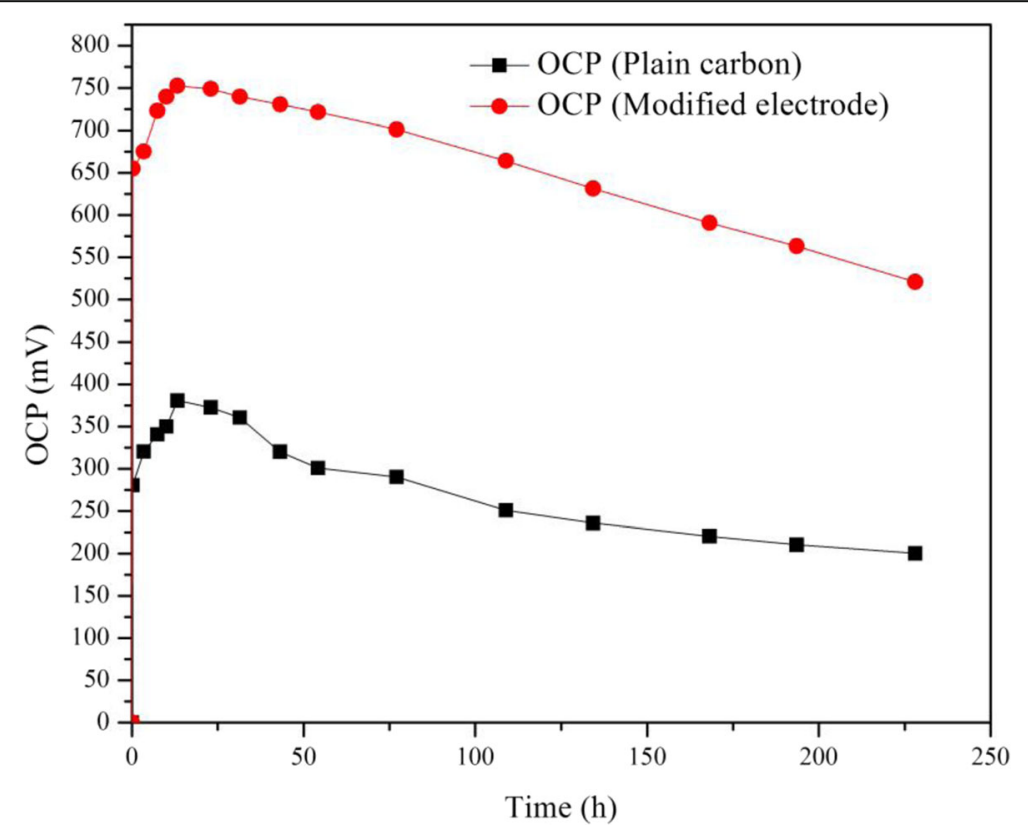

Fig. 1 Characteristics between open circuit potential (OCP) and time for plain carbon electrode and modified electrode 

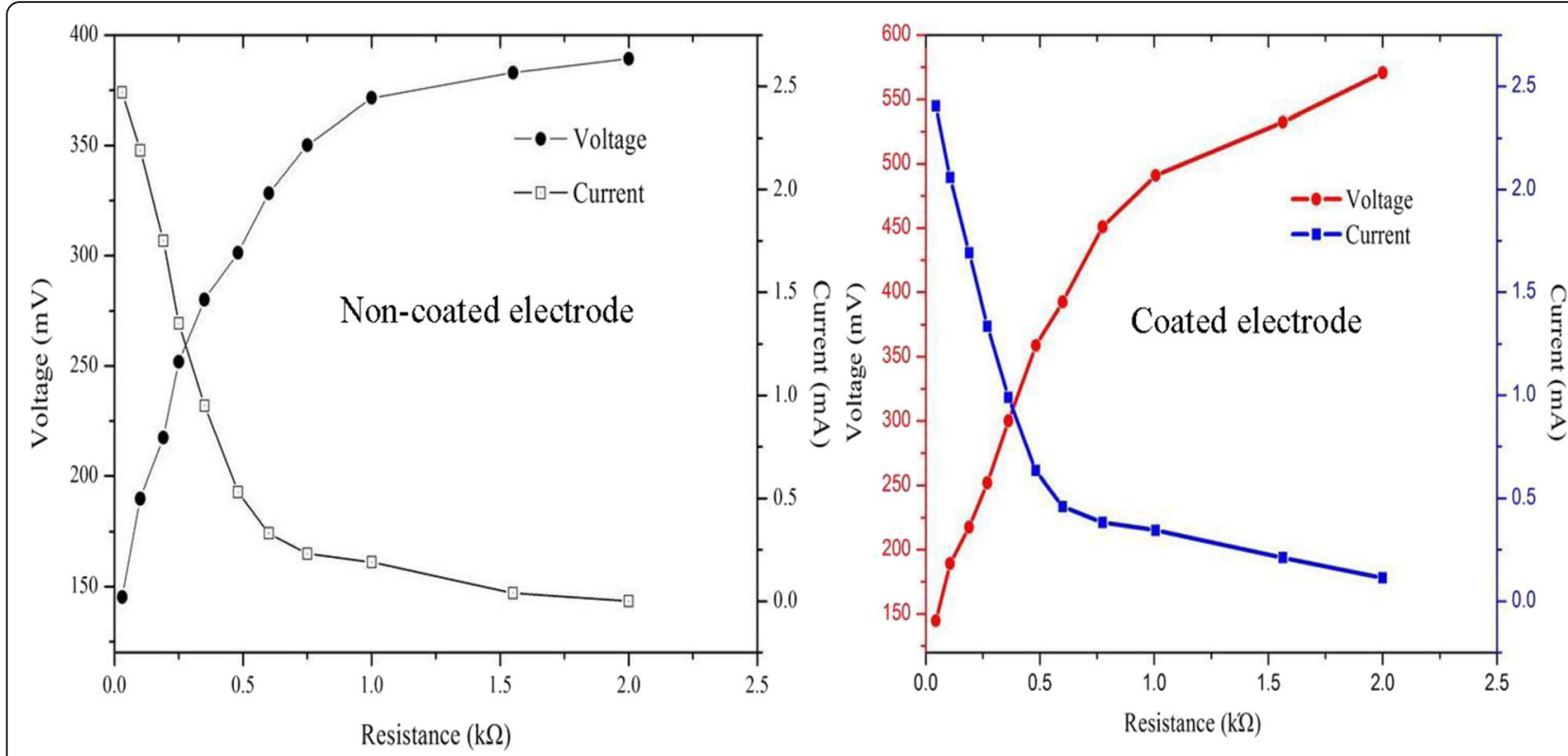

Fig. 2 Characteristics of voltage and current with respect to resistance for non- coated and coated electrode

The value of voltage is low when the value of resistance is less due to the liberation of more electrons and a maximum current generation of $2.5 \mathrm{~mA}$ is obtained at the minimum value of resistance of $0.1 \mathrm{k}^{\prime} \Omega$. The current as per the Ohm's law starts decreasing as the resistance increases; it has a maximum current of $2.4 \mathrm{~mA}$ at very low resistance value. For this maximum current of 2.4 $\mathrm{mA}$ the closed circuit voltage is $146 \mathrm{mV}$ was generated in the DB-DCMFC.
The polarization and the power density curves predict the essential influence in the performance of the DB-DCMFC. The curve drawn between the current density and the voltage is called as the polarization curve in which the value of the voltage is higher at lower current density. This shows that both the parameters are inversely proportional to each other. A peak value of $560 \mathrm{mV}$ is obtained at the current density of $6.3 \mathrm{~mA} \mathrm{~m}^{-2}$ as shown in Fig. 3. Also the power

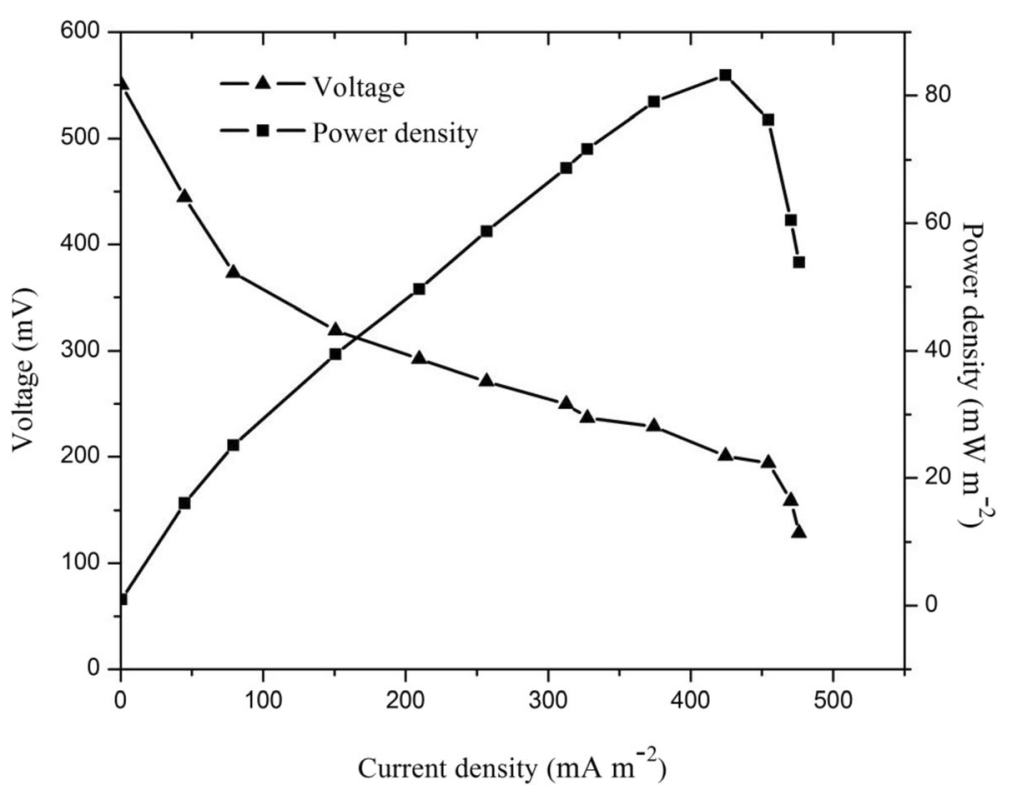

Fig. 3 Plots of voltage and power density against current density 


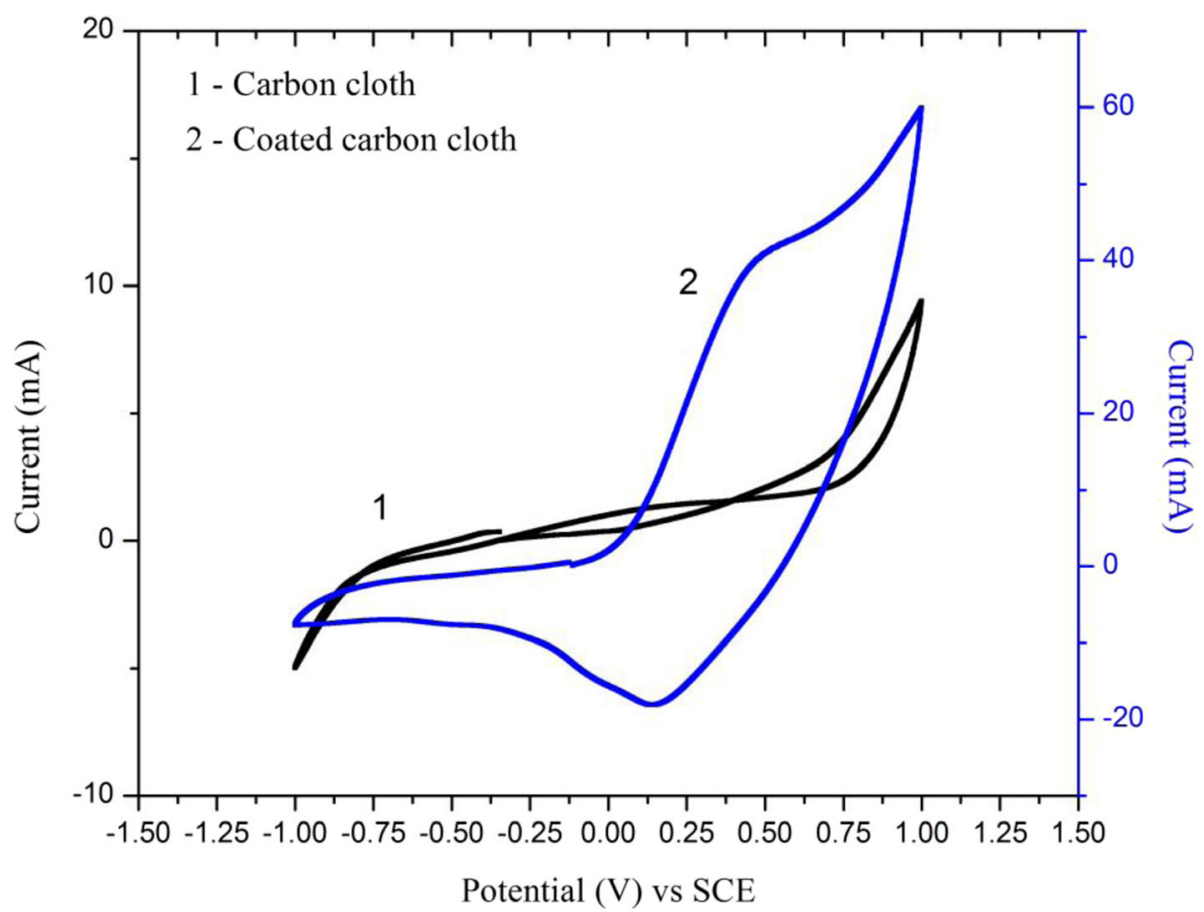

Fig. 4 Cyclic-voltammetry characteristics for plain carbon cloth and coated carbon cloth

density increases as the current density increases up to a critical value of $80 \mathrm{~mW} \mathrm{~m}^{-2}$ after which it starts decaying as shown in the Fig. 3. This shows that the power density will decay after certain value of current density.

\section{Electrochemical evaluation of electrodes}

Bioelectrochemical behavior of MFC under variable loading conditions was determined by adopting Cyclic-voltammetry (CV). This evaluates the redox activities of the components involved in bio-chemical system in solution and the components bound to the bacteria in dairy wastewater. This is helpful in finding the electro-active species of the effluent. The $\mathrm{CV}$ for plain carbon cloth electrode and cobalt oxide coated carbon cloth electrode was analyzed as shown in Fig. 4. The electron transfer to the electrode is $60 \mathrm{~mA}$ for the modified electrode which is much higher than the bare carbon cloth electrode and it shows the oxidation peak at a potential of $0.5 \mathrm{~V}$ against Standard Calomel Electrode (SCE) and the reduction peak at $0.125 \mathrm{~V}$ against SCE. The scanning rate for the CV test is $0.10 \mathrm{~V} \mathrm{~s}^{-1}$. The oxidation and the reduction reactions improved because of the effective interaction between the cobalt oxide and carbon cloth electrode. This shows that the Co (II) nitrate shows good

Table 1 Comparison of output for different electrode setup

\begin{tabular}{|c|c|c|c|c|c|}
\hline $\begin{array}{l}\text { S. } \\
\text { No. }\end{array}$ & Type of MFC & Type of influent & Current density $\left(\mathrm{mA} \mathrm{cm}^{-2}\right)$ & Electrodes used & Ref. \\
\hline 1. & $\begin{array}{l}\text { Double chamber } \\
\text { MFC }\end{array}$ & $\begin{array}{l}\text { Pure culture of Geobacter } \\
\text { sulfurreducens }\end{array}$ & 0.00025 & Graphene oxide modified cathode & [14] \\
\hline 2. & Single chamber MFC & Waste from water treatment plant & 0.0006 & $\begin{array}{l}\text { Metal doped carbonaceous } \\
\text { anodes }\end{array}$ & [25] \\
\hline 3. & $\begin{array}{l}\text { Double chamber } \\
\text { MFC }\end{array}$ & E. coli culture & 0.00061 & Porous graphite & [26] \\
\hline 4. & Single chamber MFC & Landfill leachate & $\begin{array}{l}0.14 \text { (open circuti } \\
\text { condition) }\end{array}$ & Stainless steel plates & [15] \\
\hline 5. & $\begin{array}{l}\text { Double chamber } \\
\text { MFC }\end{array}$ & Dairy wastewater & 0.00064 & Cobalt oxide coated carbon cloth & $\begin{array}{l}\text { Present } \\
\text { work }\end{array}$ \\
\hline
\end{tabular}




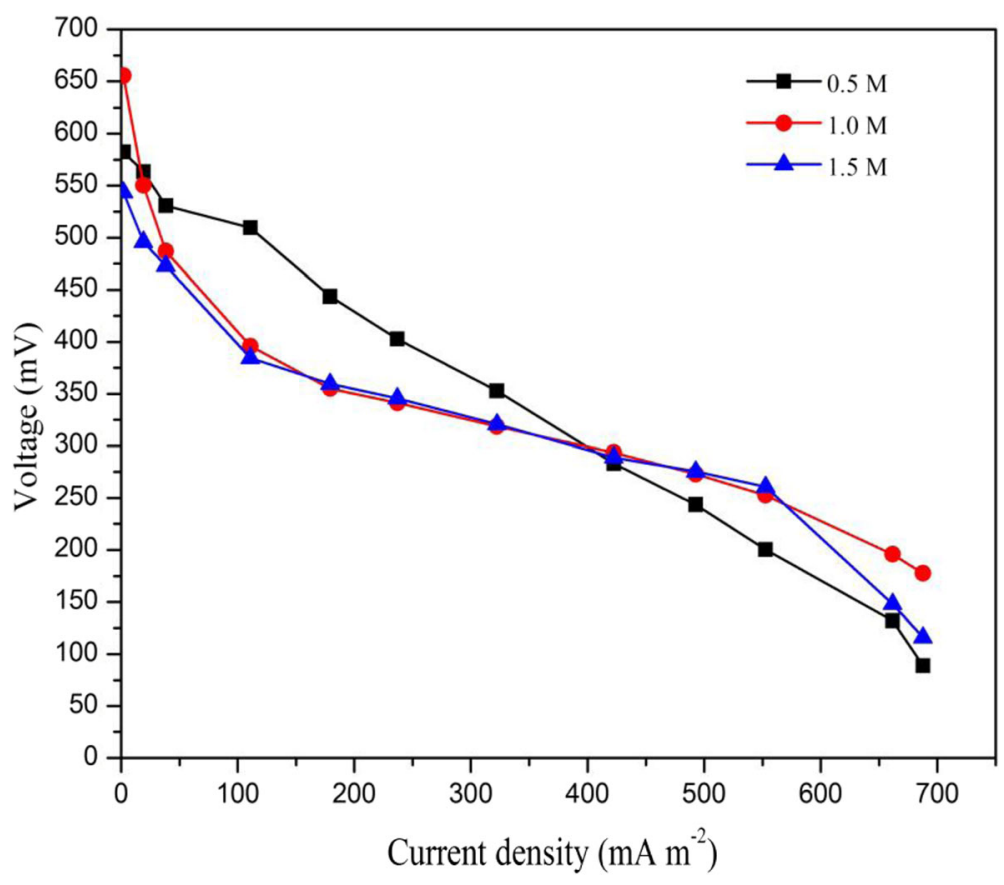

Fig. 5 Polarization curve for different concentrations of pottasium ferricyanide catholyte

electrochemical activity over the electrode surface [20]. Table 1 compares different electrodes and their output current densities. In this DB-DCMFC shows some good current density value of $0.00064 \mathrm{~mA} \mathrm{~cm}^{-2}$ comparatively shown good performance with other form of electrode used in the MFC. The power density and the current showed a better improvement for the cobalt oxide coated carbon cloth electrode.

\section{Influence of variation in potassium ferricyanide concentration}

The change in catholyte concentration influences the value of power density due to the change in the kinetics of reaction occurring in the solution. Potassium ferricyanide is a good electron acceptor which increases the power generation. The concentration is varied as $0.5,1.0$ and $1.5 \mathrm{M}$ along with phosphate buffer $\left(\mathrm{K}_{2} \mathrm{HPO}_{4}\right.$ \&

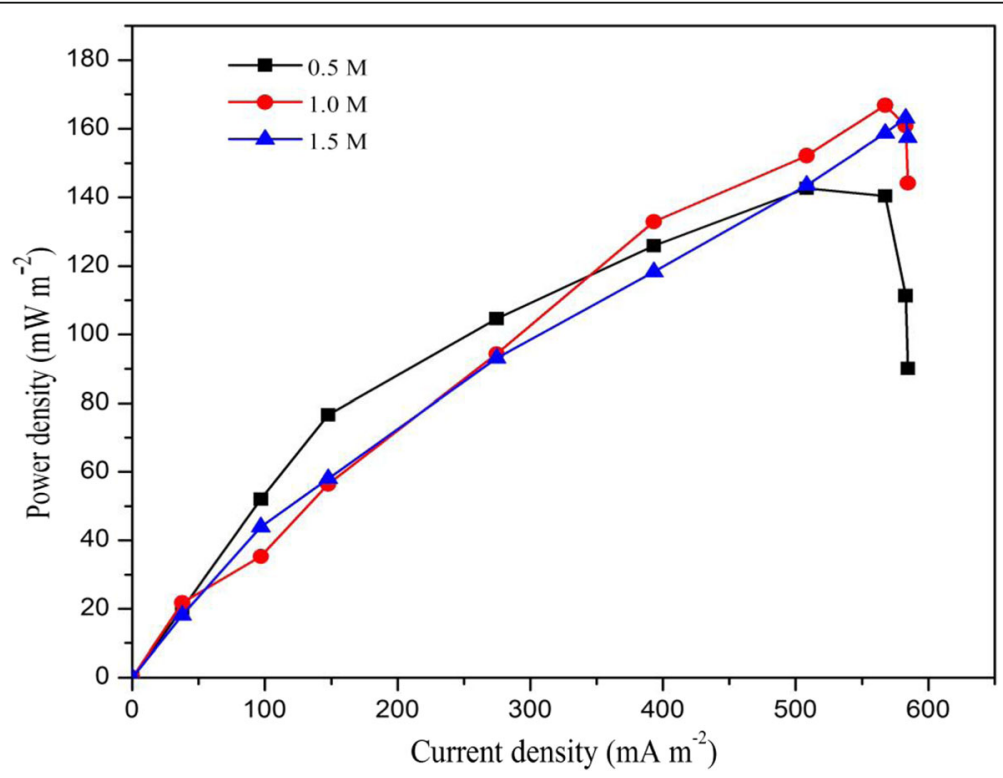

Fig. 6 Power density characteristics against current denstiy for different concentrations of pottasium ferricyanide catholyte 
$\mathrm{KH}_{2} \mathrm{PO}_{4}$ ) in equal molar volume. The test was conducted based on the variation in concentration of potassium ferricyanide and the $\mathrm{pH}$ is maintained to 7.5. The maximum open circuit voltages of the $0.5,1.0$ and $1.5 \mathrm{M}$ are 650,655 and $640 \mathrm{mV}$, respectively. For more than $1.5 \mathrm{M}$ potassium ferricyanide concentration, the voltage is depleted.

The voltage level of the DB-DCMFC with various concentrations of the catholyte is in a decreasing fashion from the maximum value as the current density increases. For $0.1 \mathrm{M}$ concentration of the potassium ferricyanide at the cathode side, a low value of current density at $2 \mathrm{~mA} \mathrm{~m}^{-2}$ with the peak voltage of $655 \mathrm{mV}$ was observed as shown in Fig. 5. The voltage levels of 582 and $543 \mathrm{mV}$ are obtained for 0.05 and $0.15 \mathrm{M}$ concentrations, respectively. The peak power density observed in this type of design is $170 \mathrm{~mW} \mathrm{~m}^{-2}$ at a current density of $590 \mathrm{~mA} \mathrm{~m}^{-2}$ for the catholyte concentration of $0.1 \mathrm{M}$ as shown in Fig. 6.

\section{Conclusions}

A two-chamber MFC with metal oxide modified electrodes in dairy wastewater was investigated. This study showed that some non-negligible amount of energy could in fact be recovered, and this could perhaps have been further increased with more aggressive process management. However, in addition to the generation and recovery of electric energy, MFCs have some additional advantages over traditional biological treatment processes, whether aerobic or anaerobic.

A comparison is made between the plain carbon cloth electrode and cobalt oxide coated carbon cloth electrode. Cobalt oxide coated in the carbon electrode improved the power density of the MFC. In this type of MFC the voltage produced is $630 \mathrm{mV}$ by a single cell of the MFC. This paper gives the method to generate electricity from dairy wastes and the performance improvement of the double chamber MFC with respect to the power density and voltage. The performance of this MFC can be improved in the future by improving the MFC output to an increased level for different low power applications.

\section{Supplementary information}

Supplementary information accompanies this paper at https://doi.org/10. 1186/s42834-020-00058-4.

Additional file 1: Figure S1. Schematic diagram of DB-DCMFC. Figure S2. Block diagram of the process of MFC. Figure S3. Hardware setup of DB-DCMFC single cell

\section{Acknowledgements}

The authors wish to thank TEQIP II of UCE, BIT campus, Anna University, Trichy for providing financial support through Teaching and Research Assistantship (TRA) for the research work.

\section{Authors' contributions}

Vinothkumar Veeramani has conducted the experimental studies on Microbial Fuel Cells for the treatment of dairy waste water. Kanimozhi Rajangam has supervised towards the experimental work on power generation and performance studies. Jaya $\mathrm{N}$ has expressed her suggestions and ideas on the chemical analysis and characteristics of the MFC. All authors read and approved the final manuscript

Funding

Not Applicable.

Availability of data and materials

Not Applicable.

\section{Competing interests}

The authors declare they have no competing interests.

\section{Author details}

${ }^{1}$ Department of Electrical and Electronics Engineering, Anna University - BIT Campus, Tiruchirappalli 620 024, India. ${ }^{2}$ Department of Petrochemical

Technology, Anna University - BIT Campus, Tiruchirappalli 620 024, India.

Received: 7 February 2020 Accepted: 26 June 2020

Published online: 29 July 2020

\section{References}

1. Davis JB, Yarbrough HF. Preliminary experiments on a microbial fuel cell. Science. 1962;137:615-6.

2. Potter MC. Electrical effects accompanying the decomposition of organic compounds. Proc R Soc Lond B. 1911;84:260-76.

3. Berk RS, Canfield JH. Bioelectrochemical energy conversion. Appl Microbiol. 1964;12:10-2.

4. Fornero JJ, Rosenbaum M, Angenent LT. Electric power generation from municipal, food, and animal wastewaters using microbial fuel cells. Electroanalysis. 2010;22:832-43.

5. Mohan Y, Kumar SMM, Das D. Electricity generation using microbial fuel cells. Int J Hydrogen Energ. 2008;33:423-6.

6. Samsudeen N, Sharma A, Radhakrishnan TK, Matheswaran M. Performance investigation of multi-chamber microbial fuel cell: an alternative approach for scale up system. J Renew Sustain Ener. 2015;7:043101.

7. Samsudeen N, Radhakrishnan TK, Matheswaran M. Performance comparison of triple and dual chamber microbial fuel cell using distillery wastewater as a substrate. Environ Prog Sustain. 2015;34:589-94.

8. Hanzhola G, Tribidasari Al, Endang S. The use of boron-doped diamond electrode on yeast-based microbial fuel cell for electricity production. J Phys Conf Ser. 2018:953:012005.

9. Rakthai S, Potchanakunakorn R, Changjan A, Intaravicha N, Pramuanl P, Srigobue $P$, et al. Electricity generation and community wastewater treatment by microbial fuel cells (MFCs). IOP Conf Ser Earth Environ Sci. 2018;150:012015.

10. Lalitha Priya R, Ramachandran T, Suneesh PV. Fabrication and characterization of high power dual chamber E coli microbial fuel cell. IOP Conf Ser Mater Sci Eng. 2016;149:012215.

11. Cai T, Meng $L$, Chen $G, X i$ Y, Jiang N, Song JL, et al. Application of advanced anodes in microbial fuel cells for power generation: a review. Chemosphere. 2020;248:125985.

12. Selvaraju $V$, Thangaraj $V$. Corrosion properties of mild steel surface modified by bright Zn-co alloy electrodeposit from acetate electrolytic bath. Mater Res Express. 2019;6:026501.

13. Selvaraju $V$, Thangaraj $V$. Influence of $y$-phase on corrosion resistance of $Z n$ $\mathrm{Ni}$ alloy electrodeposition from acetate electrolytic bath. Mater Res Express. 2018;5:056502.

14. Khalid S, Alvi F, Fatima M, Aslam M, Riaz S, Faroog R, et al. Dye degradation and electricity generation using microbial fuel cell with graphene oxide modified anode. Mater Lett. 2018;220:272-6.

15. Sonawane JM, Al-Saadi S, Raman RKS, Ghosh PC, Adeloju SB. Exploring the use of polyaniline-modified stainless steel plates as low-cost, highperformance anodes for microbial fuel cells. Electrochim Acta. 2018;268: 484-93. 
16. Pu KB, Ma Q, Cai WF, Chen QY, Wang YH, Li FJ. Polypyrrole modified stainless steel as high performance anode of microbial fuel cell. Biochem Eng J. 2018;132:255-61.

17. Chen W, Feng HJ, Shen DS, Jia YF, Li N, Ying XB, et al. Carbon materials derived from waste tires as high-performance anodes in microbial fuel cells. Sci Total Environ. 2018;618:804-9.

18. Feng HJ, Jia YF, Shen DS, Zhou YY, Chen T, Chen W, et al. The effect of chemical vapor deposition temperature on the performance of binder-free sewage sludge-derived anodes in microbial fuel cells. Sci Total Environ. 2018;635:45-52.

19. Cai T, Huang MH, Huang YX, Zheng W. Enhanced performance of microbial fuel cells by electrospinning carbon nanofibers hybrid carbon nanotubes composite anode. Int J Hydrogen Energ. 2019;44:3088-98

20. Li XJ, Wang X, Zhao Q, Wan LL, Li YT, Zhou QX. Carbon fiber enhanced bioelectricity generation in soil microbial fuel cells. Biosens Bioelectron. 2016:85:135-41.

21. Roche I, Katuri K, Scott K. A microbial fuel cell using manganese oxide oxygen reduction catalysts. J Appl Electrochem. 2010;40:13-21.

22. Li M, Zhou SQ, Xu MY. Graphene oxide supported magnesium oxide as an efficient cathode catalyst for power generation and wastewater treatment in single chamber microbial fuel cells. Chem Eng J. 2017;328:106-16.

23. Xia X, Li MC, Liu T, Liang P, Huang X. Facile synthesis of cobalt oxide as electrocatalyst for the oxygen reduction reaction in microbial fuel cells. Chem Eng J. 2018:342:395-400.

24. Raghavulu SV, Mohan SV, Goud RK, Sarma PN. Effect of anodic pH microenvironment on microbial fuel cell (MFC) performance in concurrence with aerated and ferricyanide catholytes. Electrochem Commun. 2009:11:371-5.

25. Mateo S, Canizares P, Rodrigo MA, Fernandez-Morales FJ. Driving force of the better performance of metal-doped carbonaceous anodes in microbial fuel cells. Appl Energ. 2018;225:52-9.

26. Xiong J, Hu MH, Li XP, Li HY, Li X, Liu X, et al. Porous graphite: a facile synthesis from ferrous gluconate and excellent performance as anode electrocatalyst of microbial fuel cell. Biosens Bioelectron. 2018;109:116-22.

\section{Publisher's Note}

Springer Nature remains neutral with regard to jurisdictional claims in published maps and institutional affiliations.

Ready to submit your research? Choose BMC and benefit from:

- fast, convenient online submission

- thorough peer review by experienced researchers in your field

- rapid publication on acceptance

- support for research data, including large and complex data types

- gold Open Access which fosters wider collaboration and increased citations

- maximum visibility for your research: over $100 \mathrm{M}$ website views per year

At BMC, research is always in progress.

Learn more biomedcentral.com/submissions 